\title{
Darwin, projekt i wiara katolicka *
}

Słowa mają znaczenie i to najbardziej w kontekście, w którym należy je odczytywać i rozumieć. 7 lipca 2005 roku, New York Times opublikował felieton „Finding Design in Nature” [Odnajdywanie zamysłu w przyrodzie], który rzekomo przedstawiał „oficjalne stanowisko Kościoła Katolickiego na temat ewolucji”. Autor tego felietonu, katolicki kardynał Christoph Schönborn, poprawnie ujął sprawy teologii, ale pomylił się dramatycznie w swoim rozumieniu nauki i celu ruchu ,projektu”, który istnieje w Stanach Zjednoczonych. Ponieważ wrogowie nauki w tym kraju opacznie zinterpretują te dobre słowa kardynała, należy właściwie przedstawić tę sprawę.

Jak kardynał Schönborn trafnie zauważa, Kościół katolicki nieustannie sprzeciwia się wizji życia, która wykluczałaby pojęcie Boskiego celu i znaczenia. W nowym stuleciu, jak to ujął, Kościół „bronić będzie ludzkiego rozumu utrzymując, że wewnętrzny zamysł dostrzegany w przyrodzie nie jest złudzeniem". W odpowiedzi powtórzyłbym słowa Katechizmu mówiące o tym, że naukowe badania, dotyczące ,wieku i rozwoju Wszechświata oraz rozwoju istot żywych i pojawienia się człowieka skłaniają nas do jeszcze większego podziwiania wielkości Stwórcy". Co niewątpliwie jest faktem.

* Kenneth R. Miller, Darwin, Design and Catholic Faith, http://www.millerandlevine. $\mathrm{com} / \mathrm{km} / \mathrm{evol} / \mathrm{catholic} / \mathrm{op}$-ed-krm.html. Z języka angielskiego za zgodą Autora przełożył Adam GrzyBeK. Recenzent: Józef Zon, Katedra Biologii Teroretycznej Katolickiego Uniwersytetu Lubelskiego. 
Ale Kardynał nie ma racji twierdząc, że neodarwinowska teoria ewolucji jest ze swej istoty ateistyczna. Jak mówi, neodarwinizm jest ideologią, według której ,niekierowane, niezaplanowane procesy powstawania przypadkowych zmian i doboru naturalnego" dały początek całemu życiu, także naszemu gatunkowi. Należy podkreślić to, że tak właśnie twierdziło wielu ewolucjonistów w swoich znanych pracach na temat „istoty” teorii ewolucji. Ale czy takie twierdzenia stanowią prawdziwe oblicze ewolucji, jak rozumieją ją ,poważni naukowcy”, o których mówi Kardynał?

W żadnym razie. Zastanówmy się nad słowami George'a Gaylorda Simpsona, powszechnie uważanego za jednego z głównych architektów syntezy neodarwinowskiej: ,Jest to proces [ewolucja] zachodzący całkowicie naturalnie. Osiąga on swój cel bez interwencji kogoś, kto miałby mu go nadać. Proces ten wytworzył wielki plan bez współdziałania jakiegoś projektanta. Może tak być, że zainicjowanie tego procesu i prawa fizyki, na podstawie których proces ten działa, posiadają cel i że ten mechanizm zrealizowania planu jest właśnie instrumentem Projektanta - ale o tak głębokim problemie naukowcy, jako tacy, mogą tylko milczeć".

W rzeczy samej. Tak jak powiedział Jan Paweł II, nauka nie wypowiada się na temat ostatecznego celu, który znajduje się poza dziedziną badań naukowych. Oznacza to, że ewolucjonizm biologiczny, zrozumiany poprawnie, nie stwierdza bezcelowości. Nie odnosi się ona do tego, co Simpson nazwał ,głębszym problemem”, słusznie pozostawiając go wierze.

Kardynał Schönborn także myli się, udzielając domyślnego poparcia dla ruchu ,inteligentnego projektu” w Stanach Zjednoczonych. Neokreacjoniści spod sztandaru inteligentnego projektu, w odróżnieniu od papieży Benedykta XVI i Jana Pawła II, przemawiają przeciwko ewolucji na każdym poziomie, twierdząc, że „projektant” wielokrotnie interweniował, aby bezpośrednio wytworzyć złożone formy istot żywych. Pogląd ten stoi w oczywistej sprzeczności ze słowa- 
mi dokumentu Międzynarodowej Komisji Teologicznej ${ }^{1}$ z roku 2004, które cytuje Kardynał. W rzeczywistości, dokument ten wyraża żarliwą aprobatę dla „szeroko akceptowanego wyjaśnienia” powstania i ewolucji życia, opisuje pochodzenie wszystkich żywych istot od wspólnego przodka, jako „w zasadzie pewne” oraz powtarza obserwacje Jana Pawła II dotyczące „wzmagającego się poparcia” dla ewolucjonizmu ze strony wielu dziedzin badań.

Co jednak ważniejsze, ten sam dokument wyraża się krytycznie na temat tego, jak powinniśmy interpretować badania naukowe, odnoszące się do złożoności życia: „tego, czy dostępne dane pozwalają wnioskować o słuszności projektu czy przypadkowości, nie da się ustalić na gruncie teologii. Ale należy zauważyć, że zgodnie z katolickim rozumieniem boskiej przyczynowości, prawdziwą przygodność w porządku stworzenia można pogodzić z celową boską opatrznością".

Właśnie tam, w tym prostym poglądzie, znaleźć można istotę zgodności pomiędzy ewolucjonizmem a teologią katolicką. Samą istotę ewolucji, czyli „przygodność w porządku stworzenia”, da się całkowicie pogodzić z wolą Boga. Ten oficjalny dokument Kościoła jeszcze raz podkreśla stwierdzenie, że ,nawet wynik prawdziwie przygodnego procesu naturalnego mimo to może być częścią Boskiego planu stworzenia". A ewolucja, jak uwypukla to doskonale Stephen Jay Gould w swoich pismach, jest prawdziwie przygodnym i naturalnym procesem.

Zatroskanie papieża Benedykta, wyrażone w jego wcześniejszych pismach i w jego homilii inauguracyjnej, nie dotyczy samej ewolucji, ale tego, jak ewolucję należy postrzegać we współczesnym nam świecie. Ewolucja biologiczna doskonale pasuje do tradycyjnego katolickiego rozumienia tego, jak przygodne naturalne procesy da się rozumieć jako część Boskiego planu, podczas gdy filozofie „ewolucjonistyczne", które zaprzeczają działalności Boga, nie pasują do

\footnotetext{
${ }^{1} \mathrm{http}: / /$ www.vatican.va/roman_curia/congregations/cfaith/cti_documents/rc_con_cfaith_ doc 20040723 communion-stewardship_en.html.
} 
tego rozumienia. Trzech papieży, począwszy od Piusa XII, wyraziło się na ten temat niezwykle jasno.

List Jana Pawła II do Papieskiej Akademii Nauk z 1996 roku, ${ }^{2}$ który - co jest dziwne - kardynał Schönborn uważa za „nieistotny” nosi wspaniały tytuł „Prawda nie może stać w sprzeczności z Prawdą”. W tym liście zmarły niedawno papież, pisząc w tradycji św. Augustyna i św. Tomasza z Akwinu, potwierdza zaangażowanie kościoła na dwóch płaszczyznach, naukowej racjonalności i najgłębszego duchowego rozumienia ostatecznego znaczenia i celu życia. Tak jak inni naukowcy wyznający wiarę katolicką, dostrzegam plan i cel Stworzyciela, które realizują się w naszym Wszechświecie. Widzę planetę tętniącą ewolucyjnymi możliwościami, ciągłe stwarzanie, w którym Boska opatrzność wyraża się w każdej żywej istocie. Widzę naukę, która mówi nam, że rzeczywiście istnieje projekt życia. A imieniem tego projektu jest ewolucja.

Kenneth R. Miller

${ }^{2}$ http://www.christusrex.org/www1/pope/vise10-23-96.html. 